\title{
Prevalence of anaemia, deficiencies of iron and vitamin A and their determinants in rural women and young children: a cross-sectional study in Kalalé district of northern Benin
}

\author{
Halimatou Alaofè ${ }^{1, *}$, Jennifer Burney ${ }^{2}$, Rosamond Naylor ${ }^{3}$ and Douglas Taren ${ }^{1}$ \\ 'Health Promotion Sciences Department, Mel and Enid Zuckerman College of Public Health, University of Arizona, \\ 1295 N. Martin Avenue, Campus PO Box 245163, Tucson, AZ 85724, USA: ${ }^{2}$ School of Global Policy and Strategy \\ (GPS), University of California, San Diego, La Jolla, CA, USA: ${ }^{3}$ School of Earth, Energy \& Environmental Sciences, \\ Stanford University, Stanford, CA, USA
}

Submitted 9 August 2016: Final revision received 30 November 2016: Accepted 13 December 2016: First published online 25 January 2017

\begin{abstract}
Objective: To identify the magnitude of anaemia and deficiencies of Fe (ID) and vitamin A (VAD) and their associated factors among rural women and children. Design: Cross-sectional, comprising a household, health and nutrition survey and determination of $\mathrm{Hb}$, biochemical (serum concentrations of ferritin, retinol, C-reactive protein and $\alpha_{1}$-acid glycoprotein) and anthropometric parameters. Multivariate logistic regression examined associations of various factors with anaemia and micronutrient deficiencies.

Setting: Kalalé district, northern Benin.

Subjects: Mother-child pairs ( $n$ 767): non-pregnant women of reproductive age (15-49 years) and children 6-59 months old.

Results: In women, the overall prevalence of anaemia, ID, Fe-deficiency anaemia (IDA) and VAD was $47.7,18.3,11.3$ and $17.7 \%$, respectively. A similar pattern for anaemia (82.4\%), ID (23.6\%) and IDA (21.2\%) was observed among children, while VAD was greater at $33.6 \%$. Greater risk of anaemia, ID and VAD was found for low maternal education, maternal farming activity, maternal health status, low food diversity, lack of fruits and vegetables consumption, low protein foods consumption, high infection, anthropometric deficits, large family size, poor sanitary conditions and low socio-economic status. Strong differences were also observed by ethnicity, women's group participation and source of information. Finally, age had a significant effect in children, with those aged 6-23 months having the highest risk for anaemia and those aged 12-23 months at risk for ID and IDA.

Conclusions: Anaemia, ID and VAD were high among rural women and their children in northern Benin, although ID accounted for a small proportion of anaemia. Multicentre studies in various parts of the country are needed to substantiate the present results, so that appropriate and beneficial strategies for micronutrient supplementation and interventions to improve food diversity and quality can be planned.
\end{abstract}

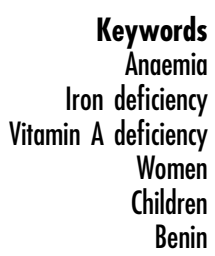

Recent reviews of dietary intake data from Benin showed that recommended daily intakes of key micronutrients, such as vitamin $\mathrm{A}$ and $\mathrm{Fe}$, were not $\mathrm{met}^{(1-4)}$. At the subnational level, in northern Benin, macronutrient intakes are also too low ${ }^{(5,6)}$. Lack of dietary diversity is a particularly severe problem in Benin where diets are based predominantly on starchy staples with little or no animal products and few fresh fruits and vegetables ${ }^{(1,2,7)}$. According to the last Demographic and Health Survey (DHS) carried out in 2012, only $28 \%$ of rural children satisfied the minimum diversity criterion of eating at least four out of seven food groups and 14\% consumed the minimum acceptable diet. In addition, the prevalence of stunting, wasting and underweight was respectively 40, 5 and 19\% among children aged 6-59 months, while $9 \%$ of rural women had chronic energy deficiency $\left(\mathrm{BMI}<18.5 \mathrm{~kg} / \mathrm{m}^{2}\right)^{(7)}$. To improve the nutrition situation of women and children in Benin, the Ministry of Health has undertaken several interventions through its Strategic Plan for Food and Nutrition Development, comprising the 
supplementation of three major nutrients (vitamin A, Fe and iodine) and other promotive activities, such as exclusive breast-feeding, appropriate complementary feeding, and improved maternal and child nutrition ${ }^{(8)}$.

Despite the efforts of the line ministry and its stakeholders, Beninese women aged 15-49 years (41\%) and children aged 6-59 months (58\%) are significantly affected by anaemia with greater prevalence in rural areas ${ }^{(7)}$. Other nutritional data, such as Fe and vitamin A status, however, were not documented in the Benin 2012 DHS. In the 2006 Benin DHS, vitamin A deficiency (VAD) as measured by serum retinol $<20 \mu \mathrm{g} / \mathrm{dl}$ was estimated to affect $66.0 \%$ of children aged 12-71 months while the prevalence of night blindness was $11.8 \%$ among pregnant women ${ }^{(9)}$. The few studies of micronutrient deficiencies among rural populations were conducted in specific localized groups and revealed greater prevalence rates of VAD among 12-71 month-old children (82\%) and pregnant women (14\%) in northern Benin ${ }^{(9)}$, while $33-49 \%$ of children under 5 years of age were Fe deficient ${ }^{(10)}$. Until now, to our knowledge, there have been no population-based studies permitting generalization about the epidemiology of anaemia and its principal determinants in non-pregnant women, despite the problem being among the top ten causes of morbidities in the country ${ }^{(11,12)}$. The only study that identified anaemia risk factors among Beninese children was carried out in 2007 and found that incomplete immunization, stunted growth, recent infection, absence of a bednet, low household living standard, low maternal education and low community development index increased the risk of anaemia ${ }^{(13)}$.

As such, identifying the magnitude of anaemia and deficiencies of $\mathrm{Fe}$ and vitamin $\mathrm{A}$ and their determinants in high-risk groups, such as women of childbearing age and children, is essential for evidence-based intervention modalities, particularly in rural areas, where women and children may suffer not only from micronutrient deficiencies but also a shortage of food ${ }^{(14)}$. The present study is a very important step forward to avail of evidence-based information on the distribution of anaemia and micronutrient deficits and their predisposing diet and health factors among rural women and children in northern Benin. It will help understand the contemporary health profile of the rural populations of the study area in terms of dietary, socio-economic and environmental factors.

\section{Methods}

\section{Location}

The study was conducted during the dry season between January and March 2014 in the Kalalé district of northern Benin. The Kalale district is home to more than 180000 people, $95 \%$ of whom rely on subsistence farming as their primary means of survival. For most, farming is limited to the rainy season due to a lack of water for irrigation ${ }^{(15)}$.
Prices for basic vegetables (tomatoes, onions, peppers, etc.) almost double during the year from the rainy season to the dry season. The lack of availability and high prices combine to severely limit diets during the dry season and malnutrition is prevalent ${ }^{(16,17)}$.

\section{Study design}

Data for the present study were obtained from a baseline survey to evaluate the expansion and implementation of commercial-scale solar-powered drip irrigation systems (solar market gardens, or SMG) that aimed at improving food security, maternal and infant nutrition status, and women's empowerment ${ }^{(18-20)}$. The cross-sectional study was conducted among sixteen villages. In each village, all households represented in women's groups (WG) were surveyed, along with a random sample of non-women's group (NWG) households from the same village; the goal was to select a maximum of thirty NWG households. In each investigated household, only one mother or caregiver of childbearing age (15-49 years) and her young child (6-59 months of age) were chosen. The first NWG household with a target mother-child in a given geographical area was selected randomly by the village delegate, and the survey continued until the required number of households was covered for each village. If there were more than one woman/child in the house, only one mother-child pair was selected. In total, 774 households were selected from the sampling frame for inclusion in the survey with 770 (311 WG $v$. 459 NWG) successfully recruited. The main reason for non-response was the failure to find individuals at home despite repeated visits to their household. Overall, 767 households were assessed, as three households of pregnant women were excluded from the analyses.

\section{Data collection}

Information on socio-economic and demographic characteristics, health status and diet factors was collected, while anthropometric measurements and blood samples were taken from the selected mother-child pairs to assess anaemia, Fe and vitamin A status. Figure 1 describes the study selection process.

\section{Sociodemographic questionnaire}

A structured questionnaire was administered to the mother of each participant child and was composed of sociodemographic information (age, education, marital status and family size), obstetric history (pregnancy), illnesses (diarrhoea, malaria and any febrile illnesses in the last 2 weeks) and qualitative dietary information, such as the frequency of consumption of plant- and animal-source foods. The socio-economic status (SES) index was constructed using principal component analysis, and included house and land ownership, housing quality (e.g. house construction materials), access to services (water, 


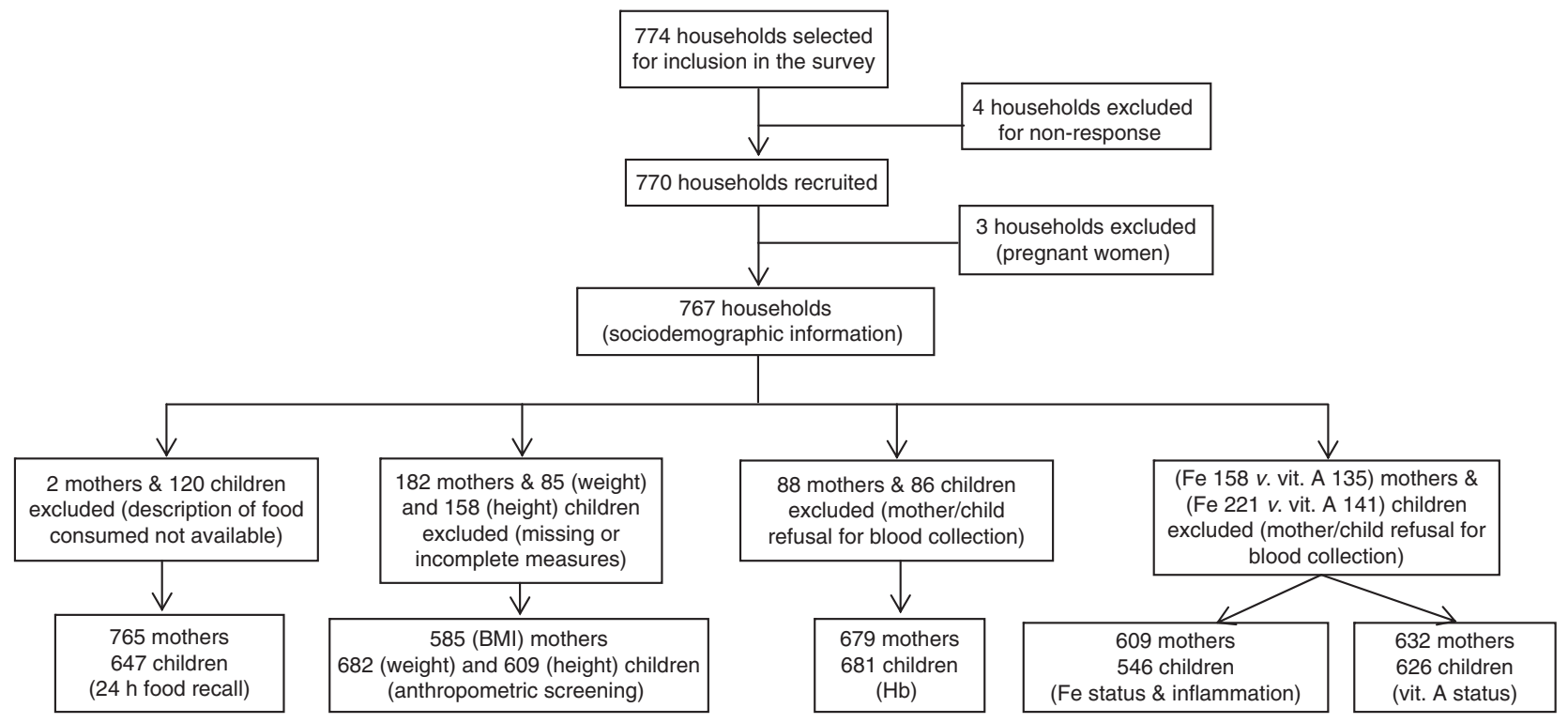

Fig. 1 Study selection process (vit. A, vitamin A)

electricity and gas) and household assets (various durable goods, agricultural machinery, animals and livestock $)^{(21,22)}$. Factor scores derived from the first factor (which explained $27 \cdot 8 \%$ of the variance) were then used to characterize the SES of each household. Households were categorized into SES quartiles based on their individual SES index score.

\section{Dietary assessment}

A qualitative recall of all foods consumed during the previous $24 \mathrm{~h}$ period was performed. Based on the FAO/ FANTA Household Dietary Diversity Questionnaire and Guidelines, the dietary data collected were computed into nine food groups for women (starchy staples; dark green leafy vegetables; vitamin-A-rich fruits and vegetables; other fruit and vegetables; organ meat; meat and fish; eggs; legumes, nuts and seeds; milk and milk products) and seven food groups for children (grains, roots and tubers; legumes and nuts; dairy products; flesh foods; eggs; vitamin-A-rich fruits and vegetables; other fruits and vegetables) ${ }^{(23)}$. The dietary diversity score (DDS) was calculated by summing the number of unique food groups and then divided into tertiles.

\section{Anthropometry}

Selected mother-child pairs were invited to come to the village health centre or school early in the morning. Both populations were weighed without shoes or sandals and wearing light clothes using a balance with a precision of $0 \cdot 1 \mathrm{~kg}$ (Body Composition Monitor Scale Tanita BC-543). Height was measured using a device with a precision of $0.1 \mathrm{~cm}$ (Shorr Board ${ }^{\circledR}$ ). For children under 2 years, measurement of recumbent length was taken on an adjustable child-length measuring board with a precision of $0.1 \mathrm{~cm}$ $\left(\right.$ Shorr Board $\left.{ }^{\circledR}\right)$. For children aged 6 months to 5 years, anthropometric $Z$-scores were calculated using the National Center for Health Statistics/WHO growth reference data of $2006^{(24)}$. Anthropometric status was assessed by the following indicators: weight-for-age $Z$-score $<-2$ for underweight; height-for-age $Z$-score $<-2$ for stunting; and weight-for-height $Z$-score $<-2$ for wasting. For women, BMI was calculated as body weight (in kilograms) divided by the square of height (in metres). Women were classified using BMI cut-off points endorsed by WHO as underweight $\left(\mathrm{BMI}<18.5 \mathrm{~kg} / \mathrm{m}^{2}\right)$, normal $\quad(\mathrm{BMI}=18.5-$ $\left.24.9 \mathrm{~kg} / \mathrm{m}^{2}\right)$, overweight $\left(\mathrm{BMI} \geq 25 \cdot 0 \mathrm{~kg} / \mathrm{m}^{2}\right)$ and obese $\left(\mathrm{BMI} \geq 30 \cdot 0 \mathrm{~kg} / \mathrm{m}^{2}\right)^{(25)}$.

\section{Blood sampling and analysis}

Just after anthropometry, venous blood ( $2 \mathrm{ml}$ for women and $1 \mathrm{ml}$ for children) was drawn by venepuncture into a sterile tube (no anticoagulant) by a licensed medical technician. $\mathrm{Hb}$ was measured immediately using the Hemocue $201^{\circledR}$ device according to the manufacturer's instructions. Five free-falling drops of blood were collected on a pre-coded special chromatography filter paper (Whatman) and dried in the shade. The dried blood spots were protected from light and stored in a plastic bag with desiccant, and the packaged dried blood spots were preserved in a refrigerator $\left(2-8^{\circ} \mathrm{C}\right)$. Then, the packaged dried blood spots were inserted into a rip-resistant envelope and sent by courier within 3 weeks to Craft Technologies, Inc. (Wilson, NC, USA), where retinol levels of the dried blood spots were estimated by the HPLC method ${ }^{(26,27)}$. The remainder of the blood sample was stored in a cool box and transported at a temperature of $4-8^{\circ} \mathrm{C}$. Within $24 \mathrm{~h}$ of sample collection, serum was obtained by centrifugation at $3000 \mathrm{~g}$ for $10 \mathrm{~min}$, then aliquoted into $0.2 \mathrm{ml}$ pre-labelled PCR tubes (Sarstedt) and kept frozen at $-20^{\circ} \mathrm{C}$ before being sent (within 3 weeks) on dry ice to VitMin Lab 
(Willstaett, Germany) for analysis of ferritin (SF), soluble transferrin receptor, body $\mathrm{Fe}$ stores, retinol-binding protein, C-reactive protein (CRP) and $\alpha_{1}$-acid glycoprotein (AGP) concentrations using a sensible sandwich ELISA technique.

Anaemia was defined according to WHO standards as $\mathrm{Hb}$ below $11 \mathrm{mg} / \mathrm{dl}$ for children aged 6 months to 5 years and below $12 \mathrm{mg} / \mathrm{dl}$ for non-pregnant women ${ }^{(26)}$. Subclinical inflammation was defined as CRP $>5 \mathrm{mg} / \mathrm{l}$ and/or AGP $>1 \mathrm{~g} / \mathrm{l}$. Four groups were defined based on CRP and AGP levels: (i) reference (normal CRP and AGP); (ii) incubation (raised CRP and normal AGP); (iii) early convalescence (raised CRP and AGP); and (iv) late convalescence (normal CRP and raised AGP). Corrected values of SF and retinol within inflammation groups were obtained by multiplying values by their respective group corrector factors: SF by 0.77 (incubation), 0.53 (early convalescence) and 0.75 (late convalescence); retinol by $1 \cdot 13$ (incubation), 1.24 (early convalescence) and 1.11 (late convalescence). For children 6-59 months, Fe deficiency (ID) was defined as $\mathrm{SF}<12 \mathrm{mg} / \mathrm{l}$ for the reference group, $\mathrm{SF}<15 \mathrm{mg} / \mathrm{l}$ for the incubation group and early convalescence group, and $\mathrm{SF}<22 \mathrm{mg} / \mathrm{l}$ for the late convalescence group. As for non-pregnant women, ID was defined as $\mathrm{SF}<15 \mathrm{mg} / \mathrm{l}$ for the reference group, $\mathrm{SF}<19 \mathrm{mg} / \mathrm{l}$ for the incubation group and early convalescence group, and $\mathrm{SF}<27 \mathrm{mg} / \mathrm{l}$ for the late convalescence group. Fe-deficiency anaemia (IDA) was defined as the combination of anaemia and $\operatorname{ID}^{(28,29)}$. Subclinical VAD was defined using WHO cut-offs as serum retinol $<20 \mu \mathrm{g} / \mathrm{dl}$ for both populations ${ }^{(28,30,31)}$.

\section{Statistical analysis}

All statistical analyses were performed using the Stata statistical software package version 14 and statistical significance was set at $P<0 \cdot 05$. To summarize data, categorical variables were expressed as percentages while continuous variables were expressed as arithmetic means, with the exception of SF, as the data were not normally distributed. SF concentrations were log-transformed before statistical analysis. Because of the high proportion of missing data for anaemia, ID, IDA and VAD (12-30\%), missing value analysis (using logistic regression and $t$ test) was conducted and revealed that outcome data were missing completely at random. Multivariable logistic regression models for anaemia and micronutrient deficiencies were obtained by using a manual backward stepwise procedure. Age, sex and setting, considered biologically and statistically relevant, and all variables associated with each of the outcomes at the $P<0.20$ level were included. At the individual level, in addition to biological variables, factors representing supplements, DDS and infections were included. Consumption of protein (meat, egg, fish or cheese) foods per week and monthly frequency of fruits and vegetables consumption were also used as indicators of diet quality, as they were highly correlated with micronutrient intakes and were a key source of bioavailable forms of $\mathrm{Fe}$ and vitamin $\mathrm{A}$. The underlying factors included household ethnicity, maternal education, maternal occupation, family size, access to health care, source of water and hygienic latrine use. SES, food insecurity and source of information were also considered. The major assumptions of logistic regression analysis (absence of multicollinearity and interaction among independent variables) were checked to be satisfied. The goodness of fit was assessed using the Hosmer-Lemeshow statistic. The adjusted odds ratio (AOR) and 95\% confidence interval were computed.

\section{Results}

\section{Sociodemographic characteristics}

Of the 767 mother-child pairs surveyed, food records were analysed for 765 mothers and 647 children, while anthropometric measurements were collected from 585 mothers, and weight and height were respectively collected from 682 and 609 children. Among the children, $48.9 \%$ were male, mean age was 21.6 months and $50.9 \%$ were under 2 years of age (Table 1). About $65.4 \%$ of the children had received vitamin A supplements in the last 6 months and the children consumed an average 3 pieces of protein foods per week. The mean DDS was $3 \cdot 1$ (out of 7) food groups, while 39.8, 23.6 and 10.9\% of the children were stunted, underweight and wasted, respectively. As for women, the majority had no formal education $(90 \cdot 3 \%)$ and most were aged $30-49$ years. Their main occupation was farming and the mean consumption of protein foods was 6 pieces per week. The women's mean DDS was 3.9 (out of 9) food groups and their mean BMI was $22.2 \mathrm{~kg} / \mathrm{m}^{2}$. Among households, mean household size was $7 \cdot 7$ members and a majority was Muslim (92.1\%). About $21.1 \%$ of households were food insecure and $33.0 \%$ had no access to health care, whereas only 13.2 and $8.2 \%$ had access to hygienic latrines and electricity connection, respectively. About $40 \%$ of households consumed fruits and vegetables two or three times per month. The highest ethnic group was Gando (34.5\%) followed by Boo (23.9\%) and other ethnic groups (Peulh, Boko, and Bariba). The main source of information was radio $(3.37 \mathrm{~d} /$ week $)$.

\section{Anaemia, iron and vitamin A status of mothers and children}

Anaemia was present in $47.7 \%$ of women while their prevalence of ID was $18.3 \%$, with $11.3 \%$ of them classified as having IDA (Table 2). The prevalence of VAD was also high, affecting $\mathbf{1 7 . 7} \%$ of surveyed women. As for inflammation status, $3 \cdot 1 \%$ had elevated CRP only, $14.0 \%$ elevated AGP only, and 5.1\% had elevated CRP and AGP. Anaemia affected more than three-quarters 
Table 1 Characteristics of children, their mothers/caregivers and their households; Kalalé district, northern Benin, January-March 2014

\begin{tabular}{|c|c|c|c|}
\hline & $n$ & $\begin{array}{l}\text { Mean or } \\
\text { prevalence }\end{array}$ & $\begin{array}{l}\text { SEM or } \\
\text { SEP }\end{array}$ \\
\hline \multicolumn{4}{|l|}{ Child characteristics } \\
\hline Age (months) & 764 & 21.59 & 0.45 \\
\hline Sex, male (\%) & 764 & 48.95 & 1.81 \\
\hline Vitamin A supplements (\%) & 751 & $65 \cdot 38$ & 1.60 \\
\hline Consumed protein foods per week ${ }^{*}$ & 702 & 3.33 & 0.13 \\
\hline DDS & 647 & $3 \cdot 10$ & 0.08 \\
\hline \multicolumn{4}{|l|}{ Child anthropometry (\%) } \\
\hline Wasting & 585 & $10 \cdot 94$ & 1.29 \\
\hline Underweight & 639 & 23.63 & 1.68 \\
\hline Stunting & 593 & $39 \cdot 80$ & $2 \cdot 01$ \\
\hline \multicolumn{4}{|l|}{ Mother/caregiver characteristics } \\
\hline Age (years) & 764 & $29 \cdot 86$ & 0.24 \\
\hline \multicolumn{4}{|l|}{ Mother's education (\%) } \\
\hline No formal education & 755 & $90 \cdot 33$ & 1.08 \\
\hline Primary or less & & $4 \cdot 37$ & 0.74 \\
\hline Secondary & & 5.03 & 0.80 \\
\hline University and more & & 0.26 & 0.19 \\
\hline \multicolumn{4}{|l|}{ Mother's occupation† (\%) } \\
\hline Agricultural/other labour & 759 & $50 \cdot 07$ & 1.82 \\
\hline Service/business & & $16 \cdot 86$ & 1.36 \\
\hline Others & & 33.07 & $1 \cdot 71$ \\
\hline $\begin{array}{l}\text { Consumed protein foods* by female } \\
\text { adults per week }\end{array}$ & 727 & $6 \cdot 01$ & $0 \cdot 13$ \\
\hline DDS & 765 & 3.87 & 0.05 \\
\hline BMI $\left(\mathrm{kg} / \mathrm{m}^{2}\right)$ & 585 & $22 \cdot 19$ & 0.13 \\
\hline \multicolumn{4}{|l|}{ Household characteristics } \\
\hline Household size & 764 & $7 \cdot 74$ & 0.14 \\
\hline \multicolumn{4}{|l|}{ Religion (\%) } \\
\hline Muslim & 767 & $92 \cdot 12$ & 0.98 \\
\hline Others & & $7 \cdot 88$ & 0.98 \\
\hline \multicolumn{4}{|l|}{ Ethnicity (\%) } \\
\hline Gando & 762 & 34.51 & 1.72 \\
\hline Boo & & 23.88 & 1.54 \\
\hline Peulh & & $15 \cdot 49$ & 1.31 \\
\hline Boko & & $11 \cdot 81$ & $1 \cdot 17$ \\
\hline Bariba & & $10 \cdot 37$ & $1 \cdot 10$ \\
\hline Others & & 3.94 & 0.70 \\
\hline \multicolumn{4}{|c|}{ Frequency of fruits and vegetables consumption (\%) } \\
\hline Never & 752 & 11.70 & $1 \cdot 17$ \\
\hline Several times per month & & 39.23 & 1.78 \\
\hline Once or twice per week & & 29.65 & 1.67 \\
\hline Almost every day & & $19 \cdot 41$ & 1.44 \\
\hline \multicolumn{4}{|l|}{ Health and sanitation (\%) } \\
\hline Latrine & 742 & $13 \cdot 21$ & 1.24 \\
\hline Safe source of water $\ddagger$ & 757 & $65 \cdot 13$ & 1.73 \\
\hline Electricity connection (\%) & 747 & $8 \cdot 17$ & 1.00 \\
\hline Food insecurity (\%) & 754 & 21.09 & 1.49 \\
\hline Health-care insecurity (\%) & 740 & 32.97 & 1.73 \\
\hline \multicolumn{4}{|l|}{ Source of information (d/week) } \\
\hline Radio & 752 & 3.37 & $0 \cdot 11$ \\
\hline Television & 753 & 0.42 & 0.05 \\
\hline
\end{tabular}

SEM, standard error of the mean; SEP, standard of error of the prevalence; DDS, dietary diversity score.

*Protein foods included meat, egg, fish and cheese.

†Agricultural/other labour = farming, livestock and hunting; services/ business $=$ small commerce, services, salaried employees and manual workers; others $=$ students and unemployed/retired.

$\ddagger$ Safe source of water included water from a tap and other sources that were treated.

(82.4\%) of the children (Table 3). Their prevalence of ID and IDA was respectively 23.6 and $21.2 \%$. One-third of children had VAD, while $38.9 \%$ had evidence of suboptimal biochemical status for both micronutrients. The children's prevalence of infection was also high:
Table 2 Vitamin A and iron status indicators and prevalence of deficiencies among non-pregnant women of reproductive age; Kalalé district, northern Benin, January-March 2014

\begin{tabular}{|c|c|c|c|}
\hline & $n$ & $\begin{array}{l}\text { Mean or } \\
\text { prevalence }\end{array}$ & SEM or SEP \\
\hline $\mathrm{Hb}(\mathrm{mg} / \mathrm{dl})$ & 679 & $11 \cdot 81$ & 0.05 \\
\hline $\mathrm{Hb}<8 \mathrm{mg} / \mathrm{dl}(\%)$ & 679 & 0.74 & 0.29 \\
\hline \multicolumn{4}{|l|}{ Fe status } \\
\hline Anaemia* (\%) & 679 & $47 \cdot 72$ & 1.92 \\
\hline $\mathrm{SF}(\mu \mathrm{g} / \mathrm{l})$ & 609 & $61 \cdot 15$ & 1.56 \\
\hline $\mathrm{SF}<30 \mu \mathrm{g} / \mathrm{l}(\%)$ & 609 & $17 \cdot 41$ & 1.54 \\
\hline $\mathrm{BIS}(\mathrm{mg} / \mathrm{kg})$ & 609 & $5 \cdot 83$ & 0.11 \\
\hline $\mathrm{BIS}<0 \mathrm{mg} / \mathrm{kg}(\%)$ & 609 & 3.78 & 0.77 \\
\hline $\mathrm{sTfR}(\mathrm{mg} / \mathrm{l})$ & 609 & $7 \cdot 47$ & 0.12 \\
\hline $\mathrm{sTfR}>8.3 \mathrm{mg} / \mathrm{l}(\%)$ & 609 & 23.97 & 1.73 \\
\hline ID† (\%) & 609 & $18 \cdot 29$ & 1.57 \\
\hline IDA‡ (\%) & 609 & 11.33 & 1.28 \\
\hline \multicolumn{4}{|l|}{ Vitamin A status } \\
\hline Serum retinol $(\mu \mathrm{g} / \mathrm{dl})$ & 632 & $31 \cdot 36$ & 0.53 \\
\hline VAD§ (\%) & 632 & $17 \cdot 72$ & 1.52 \\
\hline \multicolumn{4}{|l|}{ Inflammation || } \\
\hline $\mathrm{CRP}(\mathrm{mg} / \mathrm{l})$ & 609 & 1.96 & 0.23 \\
\hline AGP $(g / l)$ & 609 & 0.81 & 0.01 \\
\hline Elevated CRP only (\%) & 609 & $3 \cdot 12$ & $0 \cdot 70$ \\
\hline Elevated AGP only (\%) & & 13.96 & 1.40 \\
\hline Elevated CRP and AGP (\%) & & 5.09 & 0.89 \\
\hline
\end{tabular}

SEM, standard error of the mean; SEP, standard of error of the prevalence; SF, serum ferritin; BIS, body Fe stores; sTfR, soluble transferrin receptor; ID, Fe deficiency; IDA, Fe-deficiency anaemia; VAD, vitamin A deficiency; CRP, C-reactive protein; AGP, $a_{1}$-acid glycoprotein.

*Anaemia defined as $\mathrm{Hb}<12 \mathrm{mg} / \mathrm{dl}$.

†ID defined as $\mathrm{SF}<15 \mathrm{mg} / \mathrm{l}$ (with AGP and CRP normal), $<19 \mathrm{mg} / \mathrm{l}$ (with raised CRP), $<19 \mathrm{mg} / \mathrm{l}$ (with raised AGP), $<27 \mathrm{mg} / \mathrm{l}$ (with raised AGP and $\mathrm{CRP}$ ) and using corresponding correction factors for SF concentration. FIDA defined as ID deficiency and $\mathrm{Hb}<12 \mathrm{mg} / \mathrm{dl}$.

$\S V A D$ defined as serum retinol $<20 \mu \mathrm{g} / \mathrm{dl}$ (with serum retinol concentrations corrected where infection existed).

$\|$ Elevated CRP (CRP $>5 \mathrm{mg} / \mathrm{l})$ and elevated AGP $(\mathrm{AGP}>1 \mathrm{~g} / \mathrm{l})$.

elevated CRP 1.6\%, elevated AGP 29.8\%, and elevated CRP and AGP $21 \cdot 2 \%$.

\section{Associated factors of anaemia and deficiencies of iron and vitamin $A$ in mothers}

Logistic regression analysis (Table 4) revealed that infected and low-SES women had respectively 2.0 and 1.8 times greater risk of anaemia diagnosis $(P<0 \cdot 05)$. However, overweight showed a protective effect $(\mathrm{AOR}=0.46 ; 95 \%$ CI $0.24,0.88)$. On the other hand, significantly greater risk of ID was found for low DDS (AOR $=2 \cdot 13$ ), low BMI $(\mathrm{AOR}=5 \cdot 48)$, low fruits and vegetables consumption $(\mathrm{AOR}=4 \cdot 12)$ and low frequency of listening to the radio $(\mathrm{AOR}=2 \cdot 12)$, as well as in the Boo ethnic group $(\mathrm{AOR}=$ 3.01) and households without a latrine $(\mathrm{AOR}=2 \cdot 68)$. However, women's involvement in business/service was negatively associated with maternal ID $(\mathrm{AOR}=0.20$; CI $0.03,0.95$ ). Similar patterns of associations were also observed between the risk of IDA and maternal occupation, infection, and low fruits and vegetables consumption. However, women from large family size $(\mathrm{AOR}=4.02)$ had a significantly greater risk of IDA while women $30-39$ years of age $(\mathrm{AOR}=0 \cdot 40)$ had a significantly lower 
Table 3 Vitamin A and iron status indicators and prevalence of deficiencies among children aged 6-59 months; Kalalé district, northern Benin, January-March 2014

\begin{tabular}{|c|c|c|c|}
\hline & $n$ & $\begin{array}{l}\text { Mean or } \\
\text { prevalence }\end{array}$ & SEM or SEP \\
\hline $\mathrm{Hb}(\mathrm{mg} / \mathrm{dl})$ & 681 & 9.49 & 0.06 \\
\hline $\mathrm{Hb}<7$ mg/dl (\%) & 681 & 5.87 & 0.90 \\
\hline \multicolumn{4}{|l|}{ Fe status } \\
\hline Anaemia* (\%) & 681 & $82 \cdot 38$ & 1.46 \\
\hline SF $(\mu g / l)$ & 546 & $52 \cdot 73$ & $2 \cdot 12$ \\
\hline $\mathrm{SF}<30 \mu \mathrm{g} / \mathrm{l}(\%)$ & 546 & $39 \cdot 01$ & 2.09 \\
\hline BIS $(\mathrm{mg} / \mathrm{kg})$ & 546 & 2.86 & 0.17 \\
\hline $\mathrm{BIS}<0$ mg/kg (\%) & 546 & $22 \cdot 89$ & $1 \cdot 80$ \\
\hline $\operatorname{sTfR}(\mathrm{mg} / \mathrm{l})$ & 546 & 11.22 & 0.22 \\
\hline $\mathrm{sTfR}>8.3 \mathrm{mg} / \mathrm{l}(\%)$ & 546 & $67 \cdot 40$ & 2.01 \\
\hline ID† (\%) & 546 & 23.63 & 1.82 \\
\hline IDA‡ (\%) & 542 & 21.22 & 1.76 \\
\hline \multicolumn{4}{|l|}{ Vitamin A status } \\
\hline Serum retinol $(\mu \mathrm{g} / \mathrm{dl})$ & 626 & $21 \cdot 87$ & 0.33 \\
\hline VAD§ (\%) & 626 & 33.55 & 1.88 \\
\hline \multicolumn{4}{|l|}{ Inflammation || } \\
\hline CRP (mg/l)" & 543 & 4.30 & 0.35 \\
\hline AGP $(g / l)$ & 546 & 1.07 & 0.02 \\
\hline Elevated CRP only (\%) & 543 & 1.65 & 0.54 \\
\hline Elevated AGP only (\%) & 546 & 29.83 & 1.96 \\
\hline Elevated CRP and AGP (\%) & 543 & $21 \cdot 18$ & 1.75 \\
\hline
\end{tabular}

SEM, standard error of the mean; SEP, standard of error of the prevalence; SF, serum ferritin; BIS, body Fe stores; sTfR, soluble transferrin receptor; ID, Fe deficiency; IDA, Fe-deficiency anaemia; VAD, vitamin A deficiency; CRP, C-reactive protein; AGP, $a_{1}$-acid glycoprotein

*Anaemia defined as $\mathrm{Hb}<11 \mathrm{mg} / \mathrm{dl}$.

†ID defined as $\mathrm{SF}<12 \mathrm{mg} / \mathrm{l}$ (with AGP and CRP normal), $<15 \mathrm{mg} / \mathrm{l}$ (with raised CRP), $<15 \mathrm{mg} / \mathrm{l}$ (with raised AGP), $<22 \mathrm{mg} / \mathrm{l}$ (with raised AGP and $\mathrm{CRP}$ ) and using corresponding correction factors for SF concentration. FIDA defined as ID deficiency and $\mathrm{Hb}<11 \mathrm{mg} / \mathrm{dl}$.

$\S V A D$ defined as serum retinol $<20 \mu \mathrm{g} / \mathrm{dl}$ (with serum retinol concentrations corrected where infection existed).

$\|$ Elevated CRP (CRP $>5 \mathrm{mg} / \mathrm{l})$ and elevated AGP $($ AGP $>1 \mathrm{~g} / \mathrm{l})$.

risk of IDA. As for maternal VAD, the major determinants identified were lack of education ( $\mathrm{AOR}=3 \cdot 89$ ), lack of fruits and vegetables consumption ( $\mathrm{AOR}=2 \cdot 72)$, low consumption of protein foods $(\mathrm{AOR}=2.54)$ and low frequency of radio listening $(\mathrm{AOR}=1 \cdot 40)$. However, high $\mathrm{BMI} \quad(\mathrm{AOR}=0 \cdot 26$; CI 0.07, 0.92) and some ethnicities (Boo, Boko and Bariba) showed a significant protective effect. Interestingly, women with ID had a significantly greater risk of $\mathrm{VAD}(\mathrm{AOR}=1 \cdot 60$; CI $0 \cdot 13,4 \cdot 30)$.

\section{Associated factors of anaemia and deficiencies of iron and vitamin $A$ in children}

With regard to household characteristics, the risk of presenting anaemia among children was significantly greater with untreated water consumption $(\mathrm{AOR}=2 \cdot 18)$ and low frequency of radio listening $(\mathrm{AOR}=2 \cdot 15$; Table 5$)$. Children were more prone to have ID in households with low SES (AOR $=2 \cdot 89)$, low frequency of radio listening $(\mathrm{AOR}=3.46)$ and large size of five or more residents $(\mathrm{AOR}=2.79)$, whereas significantly greater risk of VAD was observed among NWG children $(\mathrm{AOR}=2 \cdot 88$; CI 1.03, 6.25). Among the maternal variables, children of underweight mothers presented a greater risk of ID $(\mathrm{AOR}=4 \cdot 06$;
$95 \%$ CI $1.31,12 \cdot 62)$ and IDA (AOR $=5.31 ; 95 \%$ CI 1.40 , $20 \cdot 14$ ) than children of mothers with normal weight. Children of farming mothers had a significantly greater risk of anaemia $(\mathrm{AOR}=2 \cdot 42 ; 95 \% \mathrm{CI} 1 \cdot 12,5 \cdot 22)$, ID $(\mathrm{AOR}=$ $2 \cdot 26 ; 95 \%$ CI 1.06, 4.78) and IDA (AOR $=4.60 ; 95 \% \mathrm{CI}$ $1 \cdot 67,12 \cdot 62$ ) compared with children of retired/student women, and children of 30-39-year-old mothers had greater anaemia risk $(\mathrm{AOR}=1.47)$ compared with children of younger women. Interestingly, children whose mothers had anaemia, IDA or VAD had equal significantly greater risk of deficiencies $(\mathrm{AOR}=2.42,2.85$ and 3.42, respectively). As for child characteristics, younger age (6-23 months) corresponded with a significantly greater risk of anaemia diagnosis, whereas 12-23-month-old children had higher risk of ID (AOR $=1 \cdot 39 ; 95 \%$ CI $1 \cdot 17$, $5.21)$ and IDA (AOR $=1.67 ; 95 \%$ CI 1.05, 4.93). The prevalence of ID $(\mathrm{AOR}=2 \cdot 17)$ and IDA $(\mathrm{AOR}=2 \cdot 16)$ was also significantly increased among stunted children, whereas low child DDS resulted in greater prevalence of anaemia $(\mathrm{AOR}=2.51 ; 95 \% \mathrm{CI} 1.08,5.86)$ and VAD $(A O R=4 \cdot 19 ; 95 \%$ CI 1.52, 11.56). Finally, the occurrence of ID, IDA and VAD was significantly greater among children with infections $(\mathrm{AOR}=3.48,1.85$ and 3.12, respectively).

\section{Discussion}

The present study showed that, according to the WHO classification $^{(28)}$, the prevalence of anaemia was a severe public health problem in both women of reproductive age and their children aged 6-59 months (>40\%). In the last Benin DHS report, anaemia prevalence in the same study area was $66.6 \%$ in children under 5 years of age and $42.4 \%$ in women of reproductive age ${ }^{(7)}$. In the present study, the prevalence of anaemia in women and children is much higher, suggesting no improvement from 2011 to 2015. Several factors might explain these findings. First, although the health authorities in Benin included different strategies to reduce child malnutrition and low birth weight, and also vitamin $\mathrm{A}, \mathrm{Fe}$ and iodine deficiencies through supplementation, food diversification and fortification $^{(13,32-34)}$, there is a lack of information to evaluate the coverage and effectiveness of these interventions at the regional level. Second, about $21 \%$ of households in the study area were reported food insecure since farming, which is the primary means of survival, is limited to the rainy season ${ }^{(5)}$. Diets are also based predominantly on starchy staples with little or no animal products and few fresh fruits and vegetables ${ }^{(1,2,7)}$. According to the 2012 Benin DHS, only 28.3 and $33.8 \%$ of children received the minimum diet diversity and minimum acceptable diet, respectively ${ }^{(7)}$, reflecting the higher rates of poverty and less diverse production portfolios in the study area. The prevalence of undernutrition among children in our sample was also greater than in the rest of the 
Table 4 Determinants of anaemia, iron and vitamin A status* among non-pregnant women of reproductive age; Kalalé district, northern Benin, January-March 2014

\begin{tabular}{|c|c|c|c|c|c|c|c|c|}
\hline & \multicolumn{2}{|c|}{ Anaemia } & \multicolumn{2}{|r|}{ ID } & \multicolumn{2}{|c|}{ IDA } & \multicolumn{2}{|c|}{ VAD } \\
\hline & AOR & $95 \% \mathrm{Cl}$ & AOR & $95 \% \mathrm{Cl}$ & AOR & $95 \% \mathrm{Cl}$ & AOR & $95 \% \mathrm{Cl}$ \\
\hline \multicolumn{9}{|l|}{ Mother/caregiver characteristics } \\
\hline \multicolumn{9}{|l|}{ Mother's age } \\
\hline $30-39$ years & $1 \cdot 12$ & $0.73,1.74$ & 0.53 & $0.20,1.38$ & 0.40 & $0.14,0.96$ & 1.09 & $0.58,2.05$ \\
\hline $40-49$ years & 1.42 & $0.65,3.06$ & 0.25 & $0.03,1.97$ & 0.66 & $0.10,4 \cdot 14$ & 0.88 & $0.25,3.12$ \\
\hline $15-29$ years & 1.00 & Ref. & 1.00 & Ref. & 1.00 & Ref. & 1.00 & Ref. \\
\hline \multicolumn{9}{|l|}{ Mother's education } \\
\hline No & \multicolumn{2}{|c|}{$n / s$} & 0.46 & $0.09,2.21$ & 1.26 & $0.21,7.50$ & 3.89 & $1.59,19.07$ \\
\hline Yes & - & - & 1.00 & Ref. & 1.00 & Ref. & 1.00 & Ref. \\
\hline \multicolumn{9}{|l|}{ Mother's occupation } \\
\hline Agricultural/other labour & \multicolumn{2}{|c|}{$n / s$} & 0.57 & $0.31,2.06$ & 0.61 & $0.15,2.55$ & 0.93 & $0.47,1.87$ \\
\hline Service/business & - & - & 0.20 & $0.03,0.95$ & $0 \cdot 15$ & $0.04,0.93$ & 2.04 & $0.82,5.07$ \\
\hline Others & - & - & 1.00 & Ref. & 1.00 & Ref. & 1.00 & Ref. \\
\hline \multicolumn{9}{|l|}{ Mother's food diversity score } \\
\hline Low & $1 \cdot 16$ & $0.70,1.93$ & $2 \cdot 13$ & $1.68,6.61$ & 1.22 & $0.39,3.77$ & 1.06 & $0.42,2.64$ \\
\hline Median & 1.01 & $0.58,1.74$ & 1.86 & $0.55,6.27$ & 0.66 & $0.17,2.51$ & 1.66 & $0.73,3.79$ \\
\hline High & 1.00 & Ref. & 1.00 & Ref. & 1.00 & Ref. & 1.00 & Ref. \\
\hline \multicolumn{9}{|l|}{ Mother's BMI } \\
\hline Underweight & 0.79 & $0.39,1.59$ & $5 \cdot 48$ & $1 \cdot 35,22 \cdot 19$ & $2 \cdot 69$ & $0.65,11 \cdot 19$ & 0.88 & $0.34,2.29$ \\
\hline Overweight & 0.46 & $0.24,0.88$ & 1.53 & $0.48,4.87$ & 1.62 & $0 \cdot 16,5 \cdot 28$ & 0.26 & $0.07,0.92$ \\
\hline Obesity & 0.30 & $0.08,1.17$ & 0.62 & $0.02,16.67$ & 0.71 & $0.21,2.49$ & 0.87 & $0.13,5.82$ \\
\hline Normal weight & 1.00 & Ref. & 1.00 & Ref. & 1.00 & Ref. & 1.00 & Ref. \\
\hline \multicolumn{9}{|l|}{ Mother's inflammation status } \\
\hline Present & 2.02 & $1.23,3.32$ & $2 \cdot 25$ & $3.19,7.05$ & 5.7 & $1.22,16.98$ & & $n / s$ \\
\hline Absent & 1.00 & Ref. & 1.00 & Ref. & 1.00 & Ref. & - & - \\
\hline \multicolumn{9}{|l|}{ Consumed protein foods } \\
\hline$\leq 4 \mathrm{pieces} /$ week & 1.16 & $0.75,1.80$ & & $n / s$ & & $n / s$ & $2 \cdot 54$ & $1.29,5.01$ \\
\hline$>4$ pieces/week & 1.00 & Ref. & - & - & - & - & 1.00 & Ref. \\
\hline Mother's ID & & & & & & & & \\
\hline Present & - & - & - & - & - & - & 1.60 & $1.13,4.30$ \\
\hline Absent & & $n / s$ & & $n / s$ & & $n / s$ & 1.00 & Ref. \\
\hline Household characteristics & & & & & & & & \\
\hline Household ethnicity & & & & & & & & \\
\hline Boo & & $\mathrm{n} / \mathrm{s}$ & 3.01 & $1.85,10.67$ & 3.08 & $0.89,10 \cdot 68$ & 0.25 & $0.11,0.59$ \\
\hline Peulh & - & - & 2.69 & $0.78,9.29$ & 2.69 & $0.85,8.50$ & 0.82 & $0.39,1.72$ \\
\hline Boko & - & - & 0.82 & $0 \cdot 16,4 \cdot 25$ & 0.44 & $0.05,3.91$ & $0 \cdot 14$ & $0.03,0.67$ \\
\hline Bariba & - & - & 0.68 & $0.14,3.36$ & 0.24 & $0.03,1.95$ & 0.27 & $0.08,0.89$ \\
\hline Gando & - & - & 1.00 & Ref. & 1.00 & Ref. & 1.00 & Ref. \\
\hline Fruits and vegetables const & & & & & & & & \\
\hline Never & 1.02 & $0.47,2.24$ & 1.27 & $0.35,4.60$ & 1.81 & $0.46,7 \cdot 10$ & 2.72 & $1.09,9.65$ \\
\hline Several times per month & $1 \cdot 16$ & $0.65,2.06$ & $4 \cdot 12$ & $1.32,3.86$ & 3.43 & $1.92,12.78$ & 1.81 & $0.77,4.24$ \\
\hline Once or twice per week & 1.45 & $0.81,2.55$ & 1.20 & $1.03,4.12$ & 0.50 & $0.09,2.86$ & 1.52 & $0.63,3.70$ \\
\hline Almost every day & 1.00 & Ref. & 1.00 & Ref. & 1.00 & Ref. & 1.00 & Ref. \\
\hline Group membership & & & & & & & & \\
\hline NWG & 0.99 & $0.64,1.55$ & 0.97 & $0.39,2.37$ & 0.42 & $0.16,1.13$ & & $n / s$ \\
\hline WG & 1.00 & Ref. & 1.00 & Ref. & 1.00 & Ref. & - & - \\
\hline Household size & & & & & & & & \\
\hline$\geq 5$ persons & $1 \cdot 15$ & $0.68,1.92$ & & $n / s$ & 4.02 & $1.91,17.69$ & & $n / s$ \\
\hline $2-4$ persons & 1.00 & Ref. & - & - & 1.00 & Ref. & - & - \\
\hline Socio-economic status & & & & & & & & \\
\hline Poorest & 1.79 & $1.01,3.20$ & $1 \cdot 18$ & $0.35,4.06$ & 1.30 & $0.34,4.91$ & 1.84 & $0.72,4.73$ \\
\hline Poor & 1.25 & $0.69,2.25$ & 0.49 & $0.12,1.95$ & 0.93 & $0.21,4.04$ & 1.58 & $0.61,4.07$ \\
\hline Intermediate & 1.15 & $0.64,2.06$ & 0.53 & $0.13,2 \cdot 21$ & 0.74 & $0.15,3.61$ & $1 \cdot 13$ & $0.44,2.91$ \\
\hline Wealthiest & 1.00 & Ref. & 1.00 & Ref. & 1.00 & Ref. & 1.00 & Ref. \\
\hline Latrine & & & & & & & & \\
\hline No & & $n / s$ & $2 \cdot 68$ & $1.45,7.26$ & 1.08 & $0.27,4.34$ & & $n / s$ \\
\hline Yes & - & - & 1.00 & Ref. & 1.00 & Ref. & - & - \\
\hline Radio news & & & & & & & & \\
\hline$\geq 3 \mathrm{~d} /$ week & & $\mathrm{n} / \mathrm{s}$ & $2 \cdot 12$ & $1.24,9.95$ & 1.27 & $0.51,3.18$ & 1.40 & $1.18,4.07$ \\
\hline$>3 \mathrm{~d} /$ week & - & - & 1.00 & Ref. & 1.00 & Ref. & 1.00 & Ref. \\
\hline
\end{tabular}

ID, Fe deficiency; IDA, Fe-deficiency anaemia; VAD, vitamin A deficiency; AOR, adjusted OR; NWG, non-women's group; WG, women's group; ref., reference category; $\mathrm{n} / \mathrm{s}$, not retained in model.

*Twenty-five independent variables were initially entered into each logistic regression equation. Variables with a $P$ value $>0.2$ were eliminated from the model (n/s).

The reported AOR are adjusted for the independent variables remaining in the equation. Bold font indicates a statistically significant association.

country (stunting $40 v .37 \%$, wasting $11 \% v .5 \%$, underweight $24 \% v$. 17 , respectively), again reflecting higher poverty rates. However, it is important to note that our data were obtained from a non-randomized study population; therefore, results should be interpreted with caution.
The measure of Fe status, not often included in surveys in Benin, indicated high prevalence of ID among women and children (>15\%), which highlights the significance of this nutritional deficit in the studied area. In 2013, Rohner et $a l .{ }^{(35)}$ found lower prevalence of ID among both populations in rural areas of the Ivory Coast: women 
Table 5 Determinants of anaemia, iron and vitamin A status ${ }^{\star}$ among children aged 6-59 months; Kalalé district, northern Benin, January-March 2014

\begin{tabular}{|c|c|c|c|c|c|c|c|c|}
\hline & \multicolumn{2}{|c|}{ Anaemia } & \multicolumn{2}{|r|}{ ID } & \multicolumn{2}{|c|}{ IDA } & \multicolumn{2}{|c|}{ VAD } \\
\hline & AOR & $95 \% \mathrm{Cl}$ & AOR & $95 \% \mathrm{Cl}$ & AOR & $95 \% \mathrm{Cl}$ & AOR & $95 \% \mathrm{Cl}$ \\
\hline \multicolumn{9}{|l|}{ Child characteristics } \\
\hline \multicolumn{9}{|l|}{ Child's age } \\
\hline $6-11$ months & 2.42 & $1.07,5.48$ & $1 \cdot 37$ & $0.70,2 \cdot 66$ & 1.11 & $0.45,2 \cdot 70$ & 0.29 & $0.08,1.02$ \\
\hline $12-23$ months & 1.93 & $1.06,3.49$ & 1.39 & $1 \cdot 17,5 \cdot 21$ & 1.67 & $1.05,4.93$ & 0.69 & $0.26,1.82$ \\
\hline 24-59 months & 1.00 & Ref. & 1.00 & Ref. & 1.00 & Ref. & 1.00 & Ref. \\
\hline \multicolumn{9}{|l|}{ Child's food diversity score } \\
\hline Low & 2.51 & $1.08,5.86$ & 1.38 & $0.27,3.53$ & $1 \cdot 18$ & $0.45,3.05$ & 4.19 & $1.52,11.56$ \\
\hline Median & 0.95 & $0.42,2.14$ & 1.18 & $0.45,3.14$ & 0.92 & $0.34,2.52$ & $2 \cdot 40$ & $0 \cdot 81,7 \cdot 10$ \\
\hline High & 1.00 & Ref. & 1.00 & Ref. & 1.00 & Ref. & 1.00 & Ref. \\
\hline \multicolumn{9}{|l|}{ Child's inflammation } \\
\hline Present & 1.53 & $0.80,2.93$ & 3.48 & $1.77,6.82$ & 1.85 & $1.26,6.41$ & $3 \cdot 12$ & $1.92,10.63$ \\
\hline Absent & 1.00 & Ref. & 1.00 & Ref. & 1.00 & Ref. & 1.00 & Ref. \\
\hline \multicolumn{9}{|l|}{ Stunting } \\
\hline Yes & & $n / s$ & $2 \cdot 17$ & $1.17,4.02$ & $2 \cdot 16$ & $1.05,4.46$ & 1.77 & $0.79,3.95$ \\
\hline No & - & - & 1.00 & Ref. & 1.00 & Ref. & 1.00 & Ref. \\
\hline \multirow{2}{*}{\multicolumn{9}{|c|}{ Mother's characteristics }} \\
\hline \multicolumn{2}{|l|}{ Mother's age } & & & & & & & \\
\hline $30-39$ years & $1 \cdot 47$ & $1.23,5.98$ & $1 \cdot 36$ & $0.70,2.66$ & 1.70 & $0.75,3.83$ & 0.75 & $0.32,1.77$ \\
\hline $40-49$ years & 0.64 & $0.22,1.86$ & 0.61 & $0.17,2.21$ & 0.97 & $0.24,3.95$ & 1.57 & $0.40,6.12$ \\
\hline $15-29$ years & 1.00 & Ref. & 1.00 & Ref. & 1.00 & Ref. & 1.00 & Ref. \\
\hline \multicolumn{9}{|l|}{ Mother's occupation } \\
\hline Agricultural/other labour & 2.42 & $1 \cdot 12,5 \cdot 22$ & 2.26 & $1.06,4.78$ & 4.60 & $1.67,12.62$ & 1.46 & $0.58,3.64$ \\
\hline Service/business & $2 \cdot 50$ & $0.87,7.16$ & $2 \cdot 07$ & $0.73,5.83$ & $2 \cdot 82$ & $0.32,7.59$ & 0.60 & $0.17,2 \cdot 11$ \\
\hline Others & 1.00 & Ref. & 1.00 & Ref. & 1.00 & Ref. & 1.00 & Ref. \\
\hline \multicolumn{9}{|l|}{ Mother's BMI } \\
\hline Underweight & $2 \cdot 04$ & $0.32,13.23$ & 4.06 & $1.31,12.62$ & $5 \cdot 31$ & $1.40,20 \cdot 14$ & $1 \cdot 18$ & $0.14,9.80$ \\
\hline Overweight & 0.62 & $0.24,1.57$ & 1.22 & $0.48,3.06$ & 1.41 & $0.47,4.24$ & 0.68 & $0.16,2.97$ \\
\hline Obesity & 1.76 & $0.43,7.21$ & 0.41 & $0.03,5.23$ & 1.09 & $0.06,8.42$ & 0.90 & $0.29,2.80$ \\
\hline \multirow{2}{*}{\multicolumn{9}{|c|}{ Mother's VAD }} \\
\hline & & & & & & & & \\
\hline Present & \multicolumn{2}{|r|}{$\mathrm{n} / \mathrm{s}$} & \multicolumn{2}{|c|}{$\mathrm{n} / \mathrm{s}$} & & $\mathrm{n} / \mathrm{s}$ & 3.42 & $1.24,9.45$ \\
\hline Absent & - & - & - & - & & & 1.00 & Ref. \\
\hline Mother's IDA & & & & & & & & \\
\hline Present & & $\mathrm{n} / \mathrm{s}$ & & $\mathrm{n} / \mathrm{s}$ & 2.85 & $1.08,7.55$ & & $\mathrm{n} / \mathrm{s}$ \\
\hline Absent & - & - & - & - & 1.00 & Ref. & - & - \\
\hline Mother's anaemia & & & & & & & & \\
\hline Present & 2.42 & $1.26,4.63$ & & $n / s$ & & $n / s$ & & $\mathrm{n} / \mathrm{s}$ \\
\hline Absent & 1.00 & Ref. & - & - & - & - & - & - \\
\hline Household characteristics & & & & & & & & \\
\hline Group membership & & & & & & & & \\
\hline NWG & $1 \cdot 18$ & $0.61,2.29$ & 1.09 & $0.57,2.07$ & 0.80 & $0.37,1.74$ & 2.88 & $1.03,6.25$ \\
\hline WG & 1.00 & Ref. & 1.00 & Ref. & 1.00 & Ref. & 1.00 & Ref. \\
\hline Household size & & & & & & & & \\
\hline$\geq 5$ persons & 1.21 & $0.57,2.56$ & 2.79 & $1.08,5.78$ & & $n / s$ & 1.64 & $0.68,3.95$ \\
\hline 2-4 persons & 1.00 & Ref. & 1.00 & Ref. & - & - & 1.00 & Ref. \\
\hline Unsafe water & & & & & & & & \\
\hline Yes & 2.18 & $1.09,4.82$ & & $n / s$ & & $n / s$ & $2 \cdot 72$ & $0.75,9.92$ \\
\hline No & 1.00 & Ref. & - & - & - & - & 1.00 & Ref. \\
\hline Socio-economic status & & & & & & & & \\
\hline Poorest & 1.07 & $0.39,2.92$ & 2.89 & $1.07,5.70$ & 1.97 & $0.67,5.78$ & 0.55 & $0.16,1.83$ \\
\hline Poor & 1.27 & $0.46,3.51$ & $1 \cdot 15$ & $0.42,3.16$ & 1.86 & $0.54,6.46$ & 0.51 & $0.14,1.78$ \\
\hline Intermediate & 0.73 & $0.29,1.84$ & 0.93 & $0.35,2.49$ & 0.79 & $0.22,2.87$ & 0.44 & $0.13,1.42$ \\
\hline Wealthiest & 1.00 & Ref. & 1.00 & Ref. & 1.00 & Ref. & 1.00 & Ref. \\
\hline Radio news & & & & & & & & \\
\hline$\leq 3 \mathrm{~d} /$ week & 2.15 & $1.06,4.36$ & 3.46 & $1.21,9.90$ & 1.32 & $0.57,3.05$ & 1.22 & $0.49,3.04$ \\
\hline$>3 \mathrm{~d} /$ week & 1.00 & Ref. & 1.00 & Ref. & 1.00 & Ref. & 1.00 & Ref. \\
\hline
\end{tabular}

ID, Fe deficiency; IDA, Fe-deficiency anaemia; VAD, vitamin A deficiency; AOR, adjusted OR; NWG, non-women's group; WG, women's group; ref., reference category; $n / s$, not retained in model.

*Thirty independent variables were initially entered into each logistic regression equation. Variables with a $P$ value $>0.2$ were eliminated from the model (n/s). The reported AOR are adjusted for the independent variables remaining in the equation. Bold font indicates a statistically significant association.

13.5 v. $18 \cdot 3 \%$ and children 8.6 v. $23.6 \%$. Geographical, economic, seasonal and behavioural variations of factors across these different settings may account for the difference. Contrary to Kassebaum et $a l .{ }^{(36)}$, ID accounted for a small proportion of anaemia (women $23.7 \%$, children $25.8 \%$ ) in the present study. A similar pattern of anaemia and ID was also observed by Nguyen et al. in Vietnam ${ }^{(37)}$, suggesting that causes for anaemia other than ID, such as other micronutrient deficiencies (vitamin A, folate or vitamin $\mathrm{B}_{12}$ ), intestinal parasites, malaria or haemoglobinopathies, could all be important factors. Haemoglobinopathies can cause a shift to the left in the Hb distribution, leading to more people having anaemia, while chronic inflammation can lead to anaemia through reduced erythropoiesis ${ }^{(38-42)}$. Unfortunately, we do not have data to identify which of these factors caused the anaemia in 
the present survey. Finally, the fact that more than half of the ID was not associated with anaemia suggests that daily Fe intake of the study population was sufficient to allow normal physiological functions but not adequate to build Fe stores. About $39 \%$ of children and $17 \%$ of women had SF concentration $<30 \mathrm{mg} / \mathrm{l}$. This is particularly important for women of reproductive age, as Fe stores of $300-500 \mathrm{mg} / \mathrm{kg}$ before pregnancy are recommended ${ }^{(43)}$.

VAD was also recognized as a public health problem among young children as more than $20 \%$ were deficient, whereas it was mild in women $(<20 \%)^{(28)}$. The 2006 Benin DHS showed a national prevalence of VAD in children of $70 \%$ and of $12 \%$ for women in the study are ${ }^{(9)}$. Although significant progress has been reported in reducing the prevalence of VAD in children, the high prevalence of VAD among both populations suggests that efforts to prevent VAD have to be maintained and even strengthened, especially for the under 5-year-old children $^{(44,45)}$. Eliminating VAD through biannual mass supplementation with vitamin A has been the focus of Beninese government efforts. About $65 \%$ of children in our sample received vitamin A supplements in the last 6 months. Of concern in the present study is that about $40 \%$ of the surveyed children were at risk of two coexisting micronutrient deficiencies. This result could explain why some interventions focused on single micronutrients such as Fe lack effectiveness in Benin. In India, for instance, vitamin A supplementation of deficient children resulted in a significant increase in $\mathrm{Hb}$ and serum $\mathrm{Fe}^{(46)}$. However, Stoltzfus found that vitamin A supplementation could not overcome ID in all settings ${ }^{(47)}$. Therefore, Beninese children need combinations of multimicronutrient sources. Other complementary types of intervention, such as food fortification or food diversification, should also be planned and evaluated.

There is evidence that ID may result in low serum retinol due to impaired enzymatic activity for the synthesis of retinol-binding protein in the liver ${ }^{(48)}$. Our positive associations between maternal VAD and ID may also be due to poor diet quality, which is an important determinant of both nutrient deficiencies in our study population $^{(49)}$. Additionally, we found that a lack of fruits and vegetables in the diet was significantly associated with ID and VAD whereas low consumption of protein foods was significantly associated with VAD, indicating that lack of access to those varieties of food items eventually deteriorates further the dietary quality of the study population $^{(50)}$. Inflammation (e.g. due to intestinal parasites or malaria) was also a risk factor for anaemia, ID, IDA and $\mathrm{VAD}$, while higher risks of anaemia and ID were found in households drinking untreated water and without a latrine. These findings suggest that more work is needed on examining the implementation of the current policy and the role of other interventions such as improvements in sanitation and hygiene that could potentially contribute to its prevention ${ }^{(51)}$. Finally, strong differences were found by ethnicity in the odds of ID and VAD. These findings serve as an important indicator of inequities in nutrition in Benin and indicate the need for further analysis of micronutrient deficiencies among and within ethnic groups.

On the other hand, most of the usual social determinants (age, family size, occupation, education and SES) showed significant associations with anaemia, ID, IDA and VAD. A similar non-nutritional factors-related trend in micronutrient deficiencies has been documented among women and children earlier ${ }^{(52-55)}$. For example, low SES was associated with increased odds of anaemia and ID while mothers' involvement in business/service was an important socio-economic factor for the non-occurrence of ID. This probably may be due to financial access to foods rich in $\mathrm{Fe}^{(50,56,57)}$. However, farming mothers in the present study had higher risk of anaemia and IDA compared with retired/ student women, highlighting the need for appropriate behaviour change communication messages that could teach caregivers about the importance of dietary quality in a child's general health. Finally, the risk of anaemia was significantly greater in our study for the 6-11 months age group and the risks of ID and IDA in the 12-23 months age group. The last DHS of infant and young child feeding practices in Benin showed that complementary foods for young children have low energy density and low protein and micronutrient content because cereal flours and cereal porridges are the most commonly used foods, which might increase the risk of $\mathrm{ID}^{(7,58)}$.

Although the present study provides useful data on prevalence of anaemia and vitamin $\mathrm{A}$ and $\mathrm{Fe}$ status in connection with dietary, socio-economic and demographic factors in vulnerable populations, it nevertheless has limitations. In Benin, seasonal undernutrition has been previously described as highly unpredictable, with considerable variations in the impact of seasonal stress within localities and even within households ${ }^{(5)}$. Serum micronutrient levels may also be affected by the time of day of blood sample collection, the fasting status of the study subjects and/or the seasonality of certain conditions such as the incidence of endemic infectious diseases. Therefore, consecutive and prospective measures are needed to better explore these associations over time. In consequence, periodical and longitudinal measurements may be desirable to test the role of seasonality in micronutrient deficiency prevalence. In addition, our results might not be generalizable to the rural Beninese population due to the non-randomization of women's groups, although no significant differences were found between WG and NWG. Another limitation of the present study is the lack of detailed information on vitamin A (timing of assessment) and $\mathrm{Fe}$ supplementation, which may provide useful information to explain the situation of micronutrient status in both populations studied. Finally, pre-analytical bias due to the complex field logistics and the samples' transport might have occurred. To reduce these potential 
biases, detailed guidelines on sample collection, preservation and transport were prepared and piloted prior to the fieldwork.

\section{Conclusion}

In summary, our findings highlight that anaemia and ID are public health problems among rural women and children in the Kalalé district of northern Benin. However, an important outcome from the study, and contrary to expectations, was that ID accounted for a small proportion of anaemia in the study area. Although the prevalence of VAD has decreased in children compared with previous surveys, VAD is still high in both populations. Furthermore, children from 12 to 59 months of age were particularly at risk of two coexisting micronutrient deficiencies, which could limit the effectiveness of programmes to optimize status for some micronutrients. Consequently, coordinated multi-micronutrient interventions for this age group are urgently needed to improve food diversity and the quality of complementary feeding. The findings also show the potential importance of programmes aimed simultaneously at improving economic, social and environmental conditions. Given the paucity of previous data in rural populations in Benin, our results represent a starting point for future research. These call for a coordinated study in various parts of the country to substantiate the current data so that appropriate and beneficial strategies for micronutrient supplementation can be planned.

\section{Acknowledgements}

Acknowledgements: The authors thank the participants and the village delegates, nurses and enumerators who participated in the study. They wish to express their very special appreciation to ADESCA-ONG, specifically Amidou Mama Sambo, Zacharie Sero Tamou and Sandra Phillips whose contribution was central to this project. Financial support: This work was supported by the University of Stanford, Hellman Fellows Program at UC San Diego and the University of Arizona. The funders had no role in the design, analysis or writing of this article. Conflict of interest: None. Authorship: J.B. and R.N. participated in the design and interpretation of the reported results. H.A. and D.T. participated in the analysis of data. All the authors participated in drafting and revising the manuscript. Etbics of buman subject participation: The study was approved by the National Ethics Committee for Health Research of Benin. Ethical clearance was obtained from the institutional review boards charged with the protection of human research subjects of the University of Arizona. All women were informed verbally about the aims and procedures of the study, and informed consent was obtained from all women and children, via their mother or guardian's approval for the latter, before enrolment.

\section{References}

1. Alaofè H, Zee J, Dossa R et al. (2008) Iron status of adolescent girls from two boarding schools in southern Benin. Public Health Nutr 11, 737-746.

2. Sodjinou R, Agueh V, Fayomi B et al. (2009) Dietary patterns of urban adults in Benin: relationship with overall diet quality and socio-demographic characteristics. Eur J Clin Nutr 63, 222-228.

3. Ochola S \& Masibo PK (2014) Dietary intake of schoolchildren and adolescents in developing countries. Ann Nutr Metab 64, 24-40.

4. Agueh VD, Tugoué MF, Sossa C et al. (2015) Dietary calcium intake and associated factors among pregnant women in southern Benin in 2014. Food Nutr Sci 6, 945-954.

5. Mitchikpe CE, Dossa RA, Ategbo EA, Van et al. (2009) Seasonal variation in food pattern but not in energy and nutrient intakes of rural Beninese school-aged children. Public Health Nutr 12, 414-422.

6. Honfo FG, Hell K, Akissoe N et al. (2010) Diversity and nutritional value of foods consumed by children in two agro-ecological zones of Benin. Afr J Food Sci 4, 184-191.

7. Institut National de la Statistique et de l'Analyse Économique \& ICF International (2013) Enquête Démographique et de Santé du Bénin 2011-2012. Calverton, MD: INSAE and ICF International.

8. Scaling Up Nutrition (2015) Strategic Processes for Scaling Up Nutrition, Benin. http://scalingupnutrition.org/sun-countries/ benin (accessed November 2015).

9. Food and Agriculture Organization of the United Nations (2011) Profil nutritionnel de pays: République du Bénin, 2011. ftp://ftp.fao.org/ag/agn/nutrition/ncp/ben.pdf (accessed November 2015).

10. Mitchikpe CE, Dossa RA, Ategbo EA et al. (2010) Growth performance and iron status of rural Beninese school-age children in post-and pre-harvest season. Afr J Food Agric Nutr Dev 10, issue 1; available at http://www.ajol.info/ index.php/ajfand/article/view/51481

11. Bodeau-Livinec F, Briand V, Berger J et al. (2011) Maternal anemia in Benin: prevalence, risk factors, and association with low birth weight. Am J Trop Med Hyg 85, 414-420.

12. Ouédraogo S, Koura GK, Accrombessi MM. et al. (2012) Maternal anemia at first antenatal visit: prevalence and risk factors in a malaria-endemic area in Benin. Am J Trop Med Hyg 87, 418-424.

13. Ngnie-Teta I, Receveur O \& Kuate-Defo B (2007) Risk factors for moderate to severe anemia among children in Benin and Mali: insights from a multilevel analysis. Food Nutr Bull 28, 76-89.

14. Alaofè H, Burney J, Naylor R et al. (2016) Solar-powered drip irrigation impacts on crops production diversity and dietary diversity in Northern Benin. Food Nutr Bull 37, 164-175.

15. Hamilton D (2015) Slavery, Memory and Identity: National Representations and Global Legacies. New York/London: Routledge.

16. Institut National de la Statistique et de l'Analyse Économique (2004) Cahier des villages et quartiers de ville du département du Borgou. http://www.insae-bj.org/recensement-population. html/Cahiers Villages 2002/ALIBORI (accessed November 2015).

17. Nierenberg D \& Halweil B (2011) State of the World 2011: Innovations that Nourish the Planet. Washington, DC: Worldwatch Institute.

18. Burney J, Woltering L, Burke M et al. (2010) Solar powered drip irrigation enhances food security in the Sudano-Sahel. Proc Natl Acad Sci U S A 107, 1848-1853.

19. Burney JA \& Naylor RL (2012) Smallholder irrigation as a poverty alleviation tool in sub-Saharan Africa. World Dev 40, 110-123. 
20. Bruhn M \& McKenzie D (2008) In Pursuit of Balance: Randomization in Practice in Development Field Experiments. Washington, DC: World Bank.

21. Vyas S \& Kumaranayake L (2006) Constructing socioeconomic status indices: how to use principal components analysis. Health Policy Plan 21, 459-468.

22. Gwatkin D, Rutstein S, Johnson K et al. (2007) Socioeconomic differences in health, nutrition, and population within developing countries: an overview. Niger J Clin Pract 10, 272-282.

23. Kennedy G, Ballard T \& Dop M (2011) Guidelines for Measuring Housebold and Individual Dietary Diversity. New York: FAO, Nutrition and Consumer Protection Division.

24. de Onis M, Onyango AW, Borghi E et al. (2006) Comparison of the World Health Organization (WHO) Child Growth Standards and the National Center for Health Statistics/ WHO international growth reference: implications for child health programmes. Public Health Nutr 9, 942-947.

25. World Health Organization (1995) Physical Status: The Use and Interpretation of Anthropometry. Report of a WHO Expert Committee. WHO Technical Report Series no. 854. Geneva: WHO.

26. Craft NE, Bulex J, Valdez C et al. (2000) Retinol concentration in capillary dried blood spots from healthy volunteers: method validation. Am J Clin Nutr 72, 450-454.

27. Craft NE, Haitema T, Brindle LK et al. (2000) Retinol analysis in dried blood spot by HPLC. J Nutr 130, 882-885.

28. World Health Organization (2006) Guidelines on Food Fortification with Micronutrients. Joint WHO/FAO Expert Consultation. Geneva: WHO.

29. Thurnham DI, McCabe LD, Haldar S et al. (2010) Adjusting plasma ferritin concentrations to remove the effects of subclinical inflammation in the assessment of iron deficiency: a meta-analysis. Am J Clin Nutr 92, 546-555.

30. De Pee S \& Dary O (2002) Biochemical indicators of vitamin A deficiency: serum retinol and serum retinol binding protein. J Nutr 132, Suppl. 9, S2895-S2901.

31. Thurnham DI, McCabe GP, Northrop-Clewes CA et al. (2003) Effects of subclinical infection on plasma retinol concentrations and assessment of prevalence of vitamin A deficiency: meta-analysis. Lancet 362, 2052-2058.

32. Sablah M, Klopp J, Steinberg D et al. (2012) Thriving publicprivate partnership to fortify cooking oil in the West African Economic and Monetary Union (UEMOA) to control vitamin A deficiency: Faire Tache d'Huile en Afrique de l'Ouest. Food Nutr Bull 33, Suppl. 3, S310-S320.

33. Omuemu VO \& Ofuani IJ (2012) Knowledge and use of zinc supplementation in the management of childhood diarrhoea among health care workers in public primary health facilities in Benin-city, Nigeria. Glob J Health Sci 2, 68 .

34. Buttriss JL, Stanner SA \& Wyness LA (2013) Nutrition and Development: Short- and Long-Term Consequences for Health. London: British Nutrition Foundation.

35. Rohner F, Northrop-Clewes C, Tschannen AB et al. (2014) Prevalence and public health relevance of micronutrient deficiencies and undernutrition in pre-school children and women of reproductive age in Cote d'Ivoire, West Africa. Public Health Nutr 17, 2016-2028.

36. Kassebaum NJ, Jasrasaria R, Naghavi M et al. (2014) A systematic analysis of global anemia burden from 1990 to 2010. Blood 123, 615-624.

37. Nguyen PH, Gonzalez-Casanova I, Nguyen H et al. (2015) Multicausal etiology of anemia among women of reproductive age in Vietnam. Eur J Clin Nutr 69, 107-113.

38. Williams TN \& Weatherall DJ (2012) World distribution, population genetics, and health burden of the hemoglobinopathies. Cold Spring Harb Perspect Med 2, a011692.
39. Gelaw A, Anagaw B, Nigussie B et al. (2013) Prevalence of intestinal parasitic infections and risk factors among schoolchildren at the University of Gondar Community School, Northwest Ethiopia: a cross-sectional study. BMC Public Health 13, 1.

40. Bain LE, Awah PK, Geraldine N et al. (2014) Malnutrition in Sub-Saharan Africa: burden, causes and prospects. Pan Afr Med J 15, 120.

41. Griffin JT, Ferguson NM \& Ghani AC (2014) Estimates of the changing age-burden of Plasmodium falciparum malaria disease in sub-Saharan Africa. Nat Commun 5, 3136.

42. Payandeh M, Rahimi Z, Zare ME et al. (2014) The prevalence of anemia and hemoglobinopathies in the hematologic clinics of the Kermanshah Province, Western Iran. Int J Hematol Oncol Stem Cell Res 8, 33.

43. Viteri FE \& Berger J (2005) Importance of pre-pregnancy and pregnancy iron status: can long-term weekly preventive iron and folic acid supplementation achieve desirable and safe status? Nutr Rev 63, Suppl. 2, S65-S76.

44. Serlemitsos JA \& Fusco H (2001) Vitamin A Fortification of Sugar in Zambia 1998-2001. Washington, DC: MOST (US Agency for International Development Micronutrient Program).

45. Fiedler JL, Mubanga F, Siamusantu W et al. (2014) Child Health Week in Zambia: costs, efficiency, coverage and a reassessment of need. Health Policy Plan 29, 12-29.

46. Mohanram M, Kulkarni KA \& Reddy V (1977) Hematological studies in vitamin A deficient children. Int J Vitam Res $\mathbf{4 7}$, 389-393.

47. Stoltzfus R (1997) Effect of maternal vitamin A or $\beta$-carotene supplementation on iron deficiency anemia in Nepalese pregnant women, postpartum mothers and infants. In Report of the XVIII IVACG Meeting, Cairo, 1977, p. 86. Washington, DC: International Vitamin A Consultative Group.

48. Oliveira JM, Michelazzo FB, Stefanello J et al. (2008) Influence of iron on vitamin A nutritional status. Nutr Rev $\mathbf{6 6}$, 141-147.

49. Olumakaiye MF (2013) Adolescent girls with low dietary diversity score are predisposed to iron deficiency in Southwestern Nigeria. ICAN Infant Child Adolesc Nutr 5, 85-91.

50. Desalegn A, Mossie A \& Gedefaw L (2014) Nutritional iron deficiency anemia: magnitude and its predictors among school age children, southwest Ethiopia: a community based cross-sectional study. PLoS One 9, e114059.

51. Pasricha SR, Drakesmith H, Black J et al. (2013) Control of iron deficiency anemia in low-and middle-income countries. Blood 121, 2607-2617.

52. Darnton-Hill I, Webb P, Harvey PW et al. (2005) Micronutrient deficiencies and gender: social and economic costs. Am J Clin Nutr 81, Suppl. 5, S1198-S1205.

53. Haidar J (2010) Prevalence of anaemia, deficiencies of iron and folic acid and their determinants in Ethiopian women. $J$ Health Popul Nutr 28, 359-368.

54. Laillou A, Van Pham T, Tran NT et al. (2012) Micronutrient deficits are still public health issues among women and young children in Vietnam. PLoS One 7, e34906.

55. Zerfu TA \& Ayele HT (2013) Micronutrients and pregnancy; effect of supplementation on pregnancy and pregnancy outcomes: a systematic review. Nutr J 12, 1.

56. Osorio MM, Lira PI \& Ashworth A (2004) Factors associated with hemoglobin concentration in children of the State of Pernambuco, Brazil. Br J Nutr 91, 307-315.

57. Maryam F, Hina R, Khawaja $\mathrm{T}$ et al. (2011) Factors responsible for iron deficiency anemia in children. J Biomed Sci Res 3, 308-314.

58. World Health Organization (2000) Complementary Feeding: Family Foods for Breastfed Children. Joint WHO/FAO Expert Consultation. Geneva: WHO. 